\title{
Immigrant Students Navigating Canadian Schools: A Longitudinal View
}

\author{
Lee Gunderson, Reginald Arthur D'Silva, \\ and Dennis Murphy Odo
}

Findings are presented from studies of the academic and language achievement of 1,307 young immigrant students whose educational history was traced from their arrival in Canada and entry into primary education in the early 1990s until their graduation from secondary schools. Five major findings are reported: school mobility, disappearance and dropout rates, success in provincial examinations, eligibility for postsecondary education, and ethnolinguistic differences in academic success. Findings reveal distinct differences in academic success related to immigrant class, gender, and first language (L1), whereas differences related to age on arrival $(A O A)$ are less apparent. These and other findings are reported and described, and implications for pedagogical policy are presented.

Nous présentons les résultats d'études portant sur le rendement académique et langagier de 1307 jeunes étudiants immigrants dont on a suivi le parcours éducationnel au Canada, de l'école primaire au début des années 1990 jusqu'à la fin de l'école secondaire. Nous traitons de cinq aspects majeurs : mobilité scolaire; disparition et décrochage; réussite aux examens de la province; admissibilité aux études postsecondaires; et différences ethnolinguistiques dans la réussite académique. Alors que les résultats révèlent des différences importantes sur le plan de la réussite académique en fonction de la classe immigrante, du sexe, de la langue maternelle, celles liées à l'âge à l'arrivée sont moins apparentes. Nous évoquons et décrivons ces résultats, et en présentons les retombées pour les politiques en matière de pédagogie.

Many immigrant students have difficulty in school (Gunderson, 2007). Various studies reveal lower achievement and higher dropout rates for immigrant students (Roessingh, 2004; Toohey \& Derwing, 2008). Results from cross-sectional studies suggest that immigrant students often struggle in schools where the language of instruction differs from the language spoken at home. The following longitudinal studies use data available from the Vancouver School District and the British Columbia Ministry of Education to track the educational history of 1,307 students who entered Canada as primary-level students in the early 1990s until their graduation from secondary school in 2009-2010. 


\section{Background}

By 2031, one in four Canadians will have been born in another country (Statistics Canada, 2010): a trend associated with increased ethnic and cultural diversity in schools (Goldenberg, 2006). To earn a "Dogwood" (i.e., officially recognized) diploma in $\mathrm{BC}$, students must write provincial exams for grade 10 language arts, science, and math. In addition, they must write grade 11 exams for social studies (or BC First Nations studies 12) and grade 12 language arts exams. These BC provincial exams are high-stakes tests. Provincial exam results for the years 2009-2010 are shown in Table 1 (data retrieved from http://www.bced.gov.bc.ca/reports/pdfs/exams/req/prov.pdf).

It is clear that ESL students are in academic jeopardy. Menken (2008) argues that disastrous consequences result from including them in high-stakes standardized tests. She concludes that the linguistic complexity of standardized tests and the lack of sufficient accommodations generally explain why English-language-learners are unable to perform as well as native-speakers. In her view, standardized tests fail as valid measures of ELL student performance. However, they are a reality in the lives of ESL students, and they clearly indicate that in the English-speaking environments of schools, ESL students are at risk of failure. These results are broad, however. They do not differentiate between students who are relatively new immigrants and those who have been in the system for most of their lives, that is, those who are part of Generation 1.5. Gunderson (2007) found that late-arriving immigrant students had lower academic achievement and exited from secondary-level academic courses at about a $60 \%$ rate, although there were significant ethnolinguistic differences when data were disaggregated, showing, for example, that refugees were more at risk than other groups. The purpose of the studies that follow was to observe the long-term success of Generation 1.5.

Table 1

Percentages of Students Failing Provincial Examinations

\begin{tabular}{lccccc}
\hline Exam & $\begin{array}{c}\text { \% of All } \\
\text { Failing } \\
\text { Students }\end{array}$ & $\begin{array}{c}\text { Total } \\
\text { Students } \\
\text { Assigned } \\
\text { an Exam } \\
\text { Mark }\end{array}$ & $\begin{array}{c}\text { \% of ESL } \\
\text { Failing } \\
\text { Students }\end{array}$ & $\begin{array}{c}\text { Total ESL } \\
\text { Students } \\
\text { Assigned } \\
\text { an Exam } \\
\text { Mark }\end{array}$ & $\begin{array}{c}\text { Failure } \\
\text { rate } \\
(\%)\end{array}$ \\
\hline English 10 & $9(N=4461)$ & 52205 & $20(N=526)$ & 2623 & 220 \\
Math 10 & $21(N=963)$ & 4570 & $49(N=29)$ & 59 & 233 \\
Science 10 & $5(N=2349)$ & 51313 & $9(N=252)$ & 2679 & 180 \\
Social studies 11 & $6(N=2911)$ & 47350 & $12(N=199)$ & 1651 & 200 \\
English 12 & $9(N=4161)$ & 44827 & $39(N=276)$ & 711 & 433 \\
\hline
\end{tabular}




\section{Theoretical Model}

Cummins $(1979,1984)$ and Cummins and Swain (1986) proposed a "Common Underlying Proficiency" (CUP) model based on the notion that "literacy-related aspects of a bilingual's proficiency in L1 and L2 are seen as common or interdependent across languages" (p. 82). Literacy experience in either language promotes the underlying interdependent proficiency base. This view suggests that "common cross-lingual proficiencies underlie the different surface manifestations of each language" (p. 82).

There is evidence to support CUP (Baker \& de Kanter, 1981; Cummins, 1983a, 1983b). Cummins (1979, 1980, 1981a, 1981b) proposed that there were two kinds of language proficiencies to be learned: "basic interpersonal communicative skill" (BICS), the language of ordinary conversation, or "the manifestation of language proficiency in everyday communicative contexts" (Cummins, 1984, p. 137) and "cognitive academic language proficiency" (CALP), the language of instruction and academic texts, which is known as academic language proficiency.

Becoming a student in a new country requires socialization into the teaching, learning, and student cultures. A second-language-learner must learn features of these cultures if he or she is to become communicatively and academically competent. Schieffelin and Ochs' $(1986 a, 1986 b)$ language socialization model has been applied to various English-as-a-second-language contexts in recent years, relating the developmental nature of L2 acquisition to sociocultural competence that L2 learners acquire over time in a target speech community (Crago, 1992; Poole, 1992; Schecter \& Bayley, 1997; Willett, 1995). In many respects, CALP is the most important feature for a student to learn to have success in secondary and postsecondary education. We visualize the process in an Inverted Funnel of Academic Socialization (IFAS). Both native and non-native learners become socialized into academic English over time. At first, socialization involves learning simple concepts and vocabulary, but over the course of academic subjects found in typical secondary schools, it becomes more complex and difficult.

As shown in Figure 1, the base of the inverted funnel is wide, and students learn BICS with little difficulty. As time passes, they must socialize into the more restricted and technical language of academic subjects; they learn CALP. The $\mathrm{Y}$ axis of Figure 1 represents this increased level of difficulty as students transition from an elementary (BICS) to a challenging (CALP) set of language skills. The black dots represent fewer and fewer students who succeed as the process becomes more demanding as they move upward in the inverted funnel through this increased level of difficulty. Many Generation 1.5 students become members of the deficit group, perceived as lacking sufficient English-language skills to be considered part of the mainstream student community. Immigrants enter what appears to be a meritocratic school system, but find that due to language barriers, they are unable to per- 


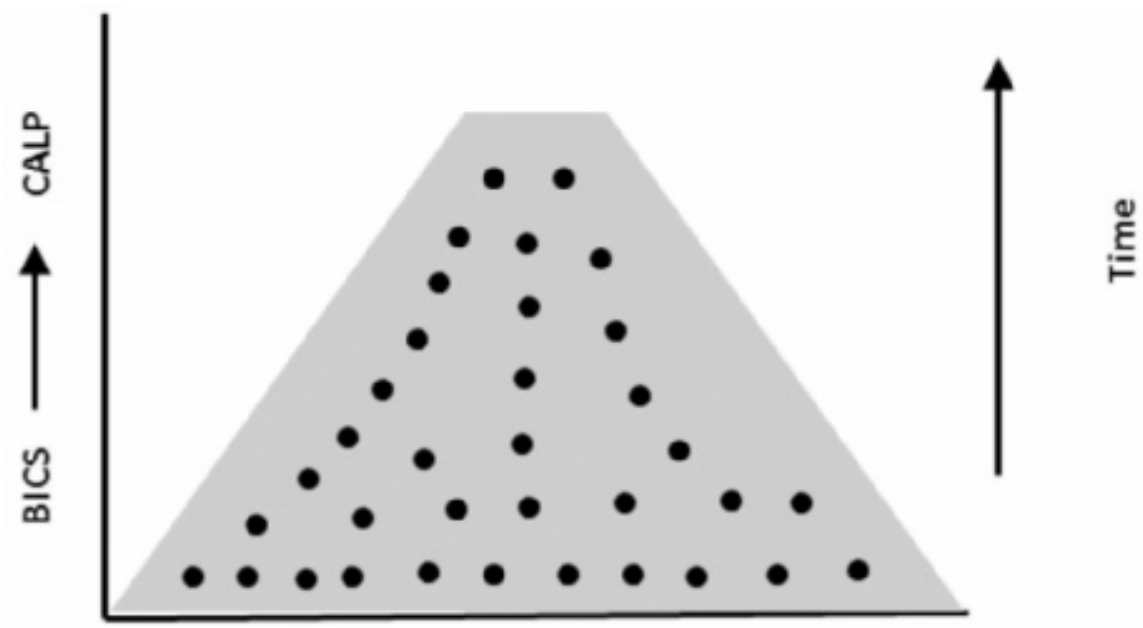

\section{Population}

Figure 1. Inverted glass funnel model.

form well in the long term, and thus they drop out with increasing frequency as they continue through the system; The greater the degree of difficulty, the fewer students remain. Another aspect represented by the model in Figure 1 is the variation in language skills as students move upward from BICS to CALP through the system. The differences between their language skills are presumably higher when they are new immigrants, mediated by their L1s, and as they are socialized into more complex language, these skills become more uniform as represented by the broad-to-narrow shaded area. The IFAS model in Figure 1, which is albeit propaedeutic, captures the important relationships between language skills, socialization, and time, and also represents a longitudinal view of how immigrant students navigate Canadian schools.

\section{Methodology}

All new students in the Vancouver School District are assessed at the Reception and Placement Centre. Approximately 2,200 a year are interviewed, assessed, and placed in schools (Gunderson, 2007). Samples for this study were drawn from two groups. The first, referred to as the Primary Group, are students who entered when they were 6-9 years of age and were enrolled in a primary grade (grades 1-3). The second group, referred to as the Intermediate Group, arrived in Canada when they were old enough to be placed in grade 4 or higher.

Permission was obtained from the Vancouver District to collect background data from the district's computerized records. The research developed background information on approximately 25,000 immigrant students 
(the Intermediate Group) who entered the district during the 1990s and early 2000s when they were enrolled in grades 4-12. In addition, permission was obtained to select a random sample $(\mathrm{N}=5,000)$ of these students to observe their high school grades in math, science, social studies, and English.

A smaller group was identified (the Primary Group). They were very young and arrived in 1995. Permission was granted to collect background information and to follow up on their academic success. Entry data were collected for all these students. They were assessed using a district-developed primary battery and were enrolled in primary classes (grades 1-3), but were not placed in ESL-support classes. Instead, they were mainstreamed into the school population. Data were collected from computerized district databases about their high school achievement, including whether they graduated. Follow-up data were collected for three separate samples from this group, which comprised 1,307 students.

\section{The Primary Group}

The 1,307 primary-level students arrived in the Vancouver School District from 82 countries. Canada (12.90\%), China $(15.10 \%)$, Hong Kong $(20.00 \%)$, the Philippines $(7.11 \%)$, and Taiwan $(11.80 \%)$ were the most common countries of origin. The boys numbered 665 and the girls 642 . About $72.00 \%$ were immigrants, and $4.00 \%$ were refugees. The large number of students born in Canada represents an interesting pattern. Families, primarily from India, chose to have their children born in Canada but raised in their home countries until of school age, when they were enrolled in primary schools in the Vancouver School District essentially as non-English-speakers.

Students and their families were interviewed in their first languages when required. They were asked to count from 1-5 and from 1-10 in English; read eight single-digit numbers and seven multiple-digit numbers; and to recite the alphabet. They were shown eight upper-case and eight lower-case letters and asked to read them. They were asked to identify six colors, pictures of six body parts, and six school items. Students were asked to follow six oral directions: Please give me the eraser; Put the ruler under the book; Open the book; Pick up the paper; Put the paper in the book, and Please close the book and put it on the table. The assessment included instructions for students to print their names, write numbers from 1-20, print the alphabet, and copy a sentence. Further, students were asked to write a story in their L1 if possible and one in English if possible. Results from these assessments were used in the predictive explorations that follow.

\section{School Mobility, Disappearance, and Dropout Rates}

Gunderson (2007) observed that $60 \%$ of the 5,000 immigrant students randomly selected from the Intermediate Group he studied disappeared from 
academic courses between grades 8 and 12 in one school district. When this statistic is disaggregated, significant differences in disappearance rates between ethnolinguistic groups are revealed. For example, Spanish-speaking refugees disappeared from academic courses at a significantly higher rate than Mandarin-speaking immigrants. These differences appeared to be associated with the socioeconomic status of the families. The difficulty with these data, however, is that disappearance does not necessarily signify dropout. Gunderson was able to track only immigrant students in a single school district, not between districts.

With the cooperation of the BC Ministry of Education, a study was designed to track Primary Group students until they graduated. From the total of 1,307, a sample of 401 born in either 1989 or 1990 was selected for study. The rationale for their selection was that in all likelihood, they would have graduated by 2009-2010. Names, dates of birth, and countries of origin were used to locate students in the Ministry of Education's database. All students had entered with their families as immigrants ( $76 \%$ immigrant, $3.2 \%$ refugee, $10.9 \%$ Canadian, $10 \%$ other) and had been interviewed and administered the assessments mentioned above in the Vancouver Reception Centre. Ministry personnel located 385 students (96\%) in their database, although 16 students could not be matched. It was concluded that these 16 students had entered the school district, been assessed and assigned to schools, but had left the district without having attended school. Using Personal Education Numbers (PENs), the Ministry can track students who move from district to district. Their database includes information about students in public and private schools, as well as those who are home-schooled. A year-by-year tracking of 385 students was produced. In 2009, 185 students graduated and had remained in the Vancouver District. These data account for $46 \%$ of those who entered in 1997. Eighty-four graduated from other school districts in the province. Therefore, a total of $269(67.10 \%)$ graduated. The remaining students $(32.90 \%)$ could not be located, so it is not clear what happened to them. The Ministry categorized them as having "out-migrated" from the province. The Ministry estimates that $80 \%$ of those who out-migrated graduated from secondary school. However, because their reasons for leaving and their destinations are unknown, there is no basis for this estimate. Toohey and Derwing (2008) explored the graduation of immigrant students from four secondary schools in the Vancouver School District and found that 933 of 1,554 students graduated (60\%). The findings of our study are approximately in agreement with Toohey and Derwing's findings, but not with those of the BC Ministry's (2009) 80\% estimate.

Mobility was a significant variable. Approximately one third of the immigrants who entered Vancouver disappeared, and 54\% left the District. These data represent subject mortality or loss of students in a study over time. However, the mobility patterns of the $54 \%$ who left the Vancouver Dis- 
trict were more complex than expected. One student, for example, enrolled in Vancouver schools from grades 1-3, then transferred to another district in grade 3 and remained there until grade 5 when she enrolled in a private school in Vancouver. She remained in private school until grade 11 and then transferred to another school district to attend grade 12 in a public school. She transferred back to Vancouver, but had to repeat grade 11 and graduated late from grade 12 in Vancouver. Another student transferred to eight school districts, but did not complete grade 12 .

Students entered their classrooms at all times of the year, coinciding with when their families had entered the country. Many stayed for only a short time, sometimes two or three weeks, until their families found permanent housing, and then moved. In addition, some students left during December to return to their home countries, returning to Vancouver after an absence of three to six weeks. Many students left for their home countries in mid-May and returned the following school year. Data revealed a 100\% change of students in some classrooms from September to June. This mobility interfered with students' learning. Mobility and study mortality were significant difficulties encountered in this study.

\section{Ethnolinguistic Differences in Academic Success}

The 1,307 Primary Group students did not receive ESL support in the school system when they first enrolled based on the notion that because they were young, they would quickly learn English in their Englishmedium primary classrooms. This belief was the operant unwritten policy in the district. Students' grades in high school academic subjects were recorded and converted to percentages according to provincial guidelines (see http://www.bced.gov.bc.ca/legislation/ schoollaw/e/ m192-94.pdf $(\mathrm{A}=86-100, \mathrm{~B}=73-85, \mathrm{C}+=67-72, \mathrm{C}=60-66, \mathrm{C}-=50-59, \mathrm{~F}=0-49$, and $\mathrm{SG}=1.00)$. The SG represents Standing Granted, which is a grade given to students who demonstrate great determination and effort, but who do not achieve a passing grade.

A comparison of grades 11 and 12 final grades in the examinable subjects (English, math, science, and social studies) revealed several discrepancies among various first-language groups' achievement. Initially, 32 language groups were listed, but most had fewer than five speakers, so the five language groups with the greatest number of speakers are shown: Korean, Mandarin, Russian, Chinese, and Tagalog. These results indicate a high disappearance rate.

The language groups with the highest achievement were the Korean- and Mandarin-speakers. The Korean-speakers had an average of $80.6 \%$ and the Mandarin-speakers $80.4 \%$ across their grades 11 and 12 examinable subjects. The Korean-speakers' scores ranged from $67.7 \%$ in grade 11 social studies to $87.6 \%$ in grade 12 science. The Mandarin-speakers' scores ranged from $76.4 \%$ in grade 12 English to $85.3 \%$ in grade 12 social studies. 
In descending order, the group with the next highest achievement was that of the Russian-speakers. Their average was $72.5 \%$ in grades 11 and 12 . Their scores ranged from an average of $55.3 \%$ in grade 12 math to $78.2 \%$ in grade 12 social studies. Cantonese-speakers' average in the examinable subjects was $69.5 \%$; their scores ranged from $66.7 \%$ in grade 12 English to $71.1 \%$ in grade 12 social studies. The final group included in this analysis included Tagalog-speakers. Unlike the Korean-, and Russian-speakers, they still had substantial numbers when they reached grade 11 . However, their numbers dropped more than $50 \%$ between grade 11 and grade 12 . This group had the lowest average grades in this analysis. Overall, their average in the exam-

Table 2

Ethnolinguistic Groups and High School Grades

\begin{tabular}{|c|c|c|c|c|c|c|c|c|c|}
\hline Home L1 & Eng 11 & Eng 12 & Math 11 & Math 12 & SS 11 & SS 12 & Sci 11 & Sci1 2 & Mean \\
\hline \multicolumn{10}{|l|}{ Korean } \\
\hline Mean & 80.7 & 83.5 & 81.2 & 82.5 & 67.7 & 87.6 & 82.0 & 80.2 & 80.6 \\
\hline $\mathrm{N}$ & 4 & 4 & 5 & 4 & 4 & 3 & 6 & 5 & \\
\hline Std. Dev. & 7.8 & 6.9 & 11.9 & 14.1 & 45.2 & 2.8 & 11.6 & 10.6 & \\
\hline \multicolumn{10}{|l|}{ Mandarin } \\
\hline Mean & 78.9 & 76.4 & 77.6 & 76.9 & 79.1 & 85.3 & 84.8 & 84.8 & 80.4 \\
\hline $\mathrm{N}$ & 54 & 39 & 56 & 39 & 54 & 32 & 45 & 38 & \\
\hline Std. Dev. & 14.6 & 20.2 & 20.6 & 26.0 & 16.7 & 32 & 8.8 & 9.5 & \\
\hline \multicolumn{10}{|l|}{ Russian } \\
\hline Mean & 72.4 & 76.0 & 73.2 & 55.3 & 72.6 & 78.2 & 77.6 & 75.3 & 72.5 \\
\hline $\mathrm{N}$ & 5 & 5 & 4 & 3 & 5 & 4 & 3 & 3 & \\
\hline Std. Dev. & 16.0 & 13.7 & 16.5 & 27.5 & 14.9 & 12.3 & 13.6 & 11.0 & \\
\hline \multicolumn{10}{|c|}{ Cantonese } \\
\hline Mean & 70 & 66.7 & 69.4 & 68.8 & 70.3 & 71.1 & 70.4 & 69.6 & 69.5 \\
\hline $\mathrm{N}$ & 81 & 59 & 81 & 53 & 76 & 42 & 71 & 45 & \\
\hline Std. Dev. & 16.0 & 18.7 & 17.6 & 25.6 & 19.1 & 21.4 & 19.1 & 24.7 & \\
\hline \multicolumn{10}{|l|}{ Tagalog } \\
\hline Mean & 64.4 & 70.3 & 53.2 & 46.8 & 65.2 & 53.4 & 55.9 & 57.5 & 58.3 \\
\hline $\mathrm{N}$ & 24 & 12 & 20 & 7 & 22 & 5 & 20 & 8 & \\
\hline Std. Dev. & 22.2 & 11.5 & 25.7 & 34.5 & 23.3 & 30.1 & 23.5 & 25.9 & \\
\hline
\end{tabular}


inable subjects in grades 11 and 12 was $58.3 \%$. Their grades ranged from an average of $46.8 \%$ in grade 12 math to $70.3 \%$ in grade 12 English.

The range in grades 11 and 12 averages in the examinable subjects was from $58.3 \%$ to $80.6 \%$, with Tagalog-speakers averaging the lowest scores and Korean- and Mandarin-speakers the highest. In grade 12 English, the range went from $70.3 \%$ to $83.5 \%$. In math it was $46.8 \%$ to $82.5 \%$; for social studies it was $53.4 \%$ to $87.6 \%$, and in science it was $57.5 \%$ to $80.2 \%$. For three of the four examinable subjects, the Tagalog-speakers had the lowest average and the Korean- or Mandarin-speakers had the highest grades. All these findings indicate discrepancies in high school achievement between the various ethnolinguistic groups examined (see Table 2 ) These results provide compelling evidence of the disappearance of immigrant students from academic courses.

\section{Eligibility for University}

Grade scores for English 12 were available for a small subset of the primary students who remained in the district. Data were available for 95 students' grade scores for English 12. These 95 students belonged to immigrant families of Asian-language backgrounds in three language categories: Mandarin $(n=34)$; Cantonese $(n=42)$; and Korean, Thai, and Filipino $(n=14)$. Their achievement in English 12 in secondary school was recorded. A 75\% (B+) grade in English-12 was used to determine a dichotomous variable that indicated whether the students would qualify for admission to postsecondary institutions in the province. We chose to limit our analysis to English12, because students' performance in the language of instruction, English, "constitutes the most decisive evidence of the likelihood of doing well in post-secondary educational programs" (Looker \& Thiessen, 2004, p. 13). In this study we employed logistic regression to explore variables that would significantly predict students' eligibility for postsecondary studies.

To explore the likelihood of students' eligibility for admission, we computed a variable to indicate whether the student had an English 12 grade that met the minimum requirements for admission to postsecondary institutions $(\mathrm{B}+$ or $75 \%)$. The numbers from the three language groups that resulted from this split are shown in Table 3. There appeared to be a fairly equal distribution of students ( $48 \%-52 \%)$. Four factors were identified as candidates for predictors: gender, placement into ESL programs, age on arrival (AOA), and home language (L1). Logistic regression analysis was carried out with these variables, and the analysis revealed a model that included three of the four predictors (AOA, gender, L1) was statistically significant.

The model that included AOA, gender, and L1 predicted a student's eligibility for college ${ }^{2}=24.20, d f=4, N=95, p<0.001$ (Nagelkerke $R^{2}=0.30$ ). The assumptions related to logistic regression were checked and met.

Students wishing to continue in postsecondary education must take prescribed courses in grade 12 and complete them with a minimum passing 
Table 3

Asian Students and English 12 Grades for College Eligibility

\begin{tabular}{lccc}
\hline Student Group and College Eligibility & No & Yes & Total \\
\hline 46 & 49 & $N=95$ \\
$48 \%$ & $52 \%$ & \\
\hline
\end{tabular}

grade. Students choose courses in science, math, social studies, and English. Only the grade for English 12 was used for this analysis; however, students' grades were available from grades 8-12. The mean grades in English, along with standard deviations (SD), are listed in Table 3. Grades appeared to change marginally between grade 8 and grade 12 for all language groups. The Mandarin-speakers performed on average better than the Cantonesespeakers and other Asian-language-speakers. Further, a look at the mean grade values indicates that the Mandarin and other Asian-language-speakers on average were eligible for enrollment in university at a higher rate than the Cantonese group. Good average grades in high school are important indicators of future attendance in college and university (Looker \& Thiessen, 2004). However, this observation masks trends observed in the descriptive statistics for the three predictor variables and revealed by the logistic regression analysis: gender, home language, and AOA.

The findings indicated that of the three language groups, the Cantonesespeakers were the least likely to qualify for college. Future research will have to investigate the cause of this discrepancy. The descriptive statistics reinforce the findings of the logistic regression that make the Mandarin group the most successful with the highest number of students eligible for college.

Mandarin-speakers generally arrive from mainland China and Taiwan. Gunderson (2007) notes that the Taiwanese immigrant families, socioeconomically advantaged and resourceful, mobilized their social and financial capital to provide alternate means of support for their children's learning to

Table 4

Student Performance in English Along with SD (in parentheses)

\begin{tabular}{lccccc}
\hline \multicolumn{5}{c}{ Grade Averages of Students in English By Home Language } \\
\hline Home Language & Grade 8 & Grade 9 & Grade 10 & Grade 11 & Grade 12 \\
\hline Mandarin & $80.4(9.9)$ & $81.9(8.6)$ & $81.6(6.6)$ & $78.9(17.0)$ & $80.2(9.7)$ \\
Cantonese & $68.1(10.9)$ & $70.0(10.5)$ & $71.1(9.4)$ & $70.7(9.7)$ & $69.2(10.7)$ \\
Other Asian & $75.3(5.8)$ & $75.6(10.0)$ & $77.2(8.2)$ & $76.5(10.5)$ & $75.1(11.3)$ \\
\hline
\end{tabular}


ensure their academic success. Some of these students had one to four tutors who accompanied them even during travel to increase learning opportunities and assist with their schoolwork. It is likely that the parents' personal investment in their children's education and their drive to enable their children to succeed in Canadian schools were among the other reasons for this group's high academic achievement.

The ghetto notion of ESL programs held by students leads to their reluctance to participate in such programs, notes Gunderson (2007), while another independent study in the same school district reports that "students [also] felt the ESL program prevented them from taking the more meaningful credit courses required for college and university entrance" (Minichiello, 2001, p. 88). A disincentive for students to remain in ESL classes is that no academic credits are attached to ESL courses in the province. Parents are probably reluctant to allow their children to continue with ESL support courses because the courses seem unrelated to academic achievement that counts toward graduation. Given that academic performance in English through high school is an important metric for eligibility for college (Looker \& Thiessen, 2004), it has a significant effect on students' participation in postsecondary education programs (PSEPs).

In addition, gender was a significant predictor of college eligibility. Although the sample consisted of a greater number of women $(N=95$, women=51, men=44), a greater proportion of women met the eligibility criterion. When grouped by gender, a majority of women in the group qualified for college (61\% or 31 in 51), whereas the men who qualified were in the minority $(41 \%$ or 18 in 44). This finding supports the results of the logistic regression and the trends seen in a number of studies that suggest that women have higher academic achievement and college participation (Portes \& Rumbaut, 2001). These results suggest that given better performance on high-school grades, girls may be more likely to qualify for enrollment in PSEPs, and college participation numbers indeed indicate these trends. The Youth in Transition Survey (YITS) that tracks the postsecondary experiences of young adults across Canada reported that "participation in postsecondary education was more prevalent among women" (Lambert et al., 2004, p. 8). The YITS survey found that women outnumbered men in terms of participation in PSEPs (77\% to $66 \%$ ) in 1999, and the trend continued in 2001.

\section{Summary and Conclusions}

A persistent notion in teaching and learning folklore is that there is merit in the sink-or-swim approach, particularly for very young learners. Inherent in this approach is the belief that young ESL students will acquire both BICS and CALP by osmosis from their native-speaking classmates and the standard mainstream curriculum. It seems clear from the results of this study that although some students survive and graduate from high school, many do not. 
Findings suggest that the inverted funnel model of ESL students' academic achievement has some merit. As the level of course-based knowledge increases over time, fewer ESL students remain in secondary school academic classes. Further, it is clear that students in high schools are difficult to track. As Gunderson (2007) notes,

Schools are social institutions in which young human beings are involved in instruction designed according to curricula often mandated by administrators, policy makers, or educators in jurisdictions such as Provincial Ministries of Education, State Departments of Education, or, so it seems, by federal governments funding certain kinds of instructional programs and not others. They are also institutions where young human beings interact with other young human beings and significant adults. Students spend many hours growing up in schools. Both their minds and their bodies undergo miraculous changes. As social institutions containing micro-societies comprised of students, teachers, administrators, counselors, paraprofessionals, librarians, custodians, secretaries, parent volunteers, occasionally police officers, and others, schools are not the best places to conduct scientific research. The normal state of affairs in a school is one of great flux and change. It is likely impossible to conduct scientific research in a typical school because there are too many confounding variables to control. (p. $\mathrm{x}$ )

Long-term research involving immigrant students turns out to be particularly difficult. Gunderson (2007) found that in the school district that he studied, $60 \%$ of the 5,000 late-arriving immigrant students whom he studied disappeared from academic classes by grade 12 , whereas $46 \%$ of the early-arriving immigrants in the present study had remained in grade 12 . However, only about $10 \%$ were enrolled in the academic classes required for admission to university. Watt and Roessingh's (2001) study showed a 73\% dropout rate in Alberta. Student mobility was a multifaceted feature in the present study with high inter- and intra-district mobility. Over time, about $54 \%$ left the school district, and close to one third of the students disappeared from provincial schools altogether, making it impossible to track them to find out if they had dropped out or left the province to attend school in other jurisdictions. It is clear, however, that some immigrant groups were more likely to disappear than others, which leaves us to question whether equal access to education is a real or imagined feature of Canadian schools.

Garnett, Adamuti-Trache, and Ungerleider (2008) adopted another methodological approach by exploring the academic achievement of 4,075 grade 12 students in 18 secondary schools in one BC school district. They concluded, "Chinese speakers retain a performance advantage over all other ethnolinguistic groups in English and math and Overall scores" (p. 320). 
These authors used the category Chinese speakers rather than breaking it down into Mandarin- and Cantonese-speaking. Generally, however, their results show differences related to ethnolinguistic groups.

Little research has focused on the high-school achievement of diverse ethnolinguistic groups. However, Rumbaut's (1995) study of 80,000 learners in the ethnically diverse San Diego Unified School District revealed that the highest GPAs belonged to Chinese, Korean, Japanese, Vietnamese, and Filipino students. When data are disaggregated, it is found that some Asian linguistic groups have higher academic achievement than others: Chinese (Abada \& Tenkorang, 2009; Gunderson, 2007; Louie, 2001), Korean (Canadian Council on Learning [CCL], 2008), and South Asian (Indian and Pakistani, Pfeifer \& Lee, 2004). The CCL found that Chinese and Korean learners outperformed other language groups in math and science in high school. Other research by Steinberg (1996) indicates higher achievement for Asian-American students than for European-American students.

These differences in achievement among the various ethnolinguistic groups need to be addressed. Ideally, more research into what relative L1 skills might be variably affecting these students' English acquisition is essential. In addition, it is important to investigate other factors that might cause the discrepancy in achievement among diverse L1 groups. For example, it would be beneficial to explore why some Asian groups, who are ostensibly similar demographically, still outperform others (Mandarin and Korean). The question may be about what other variables, in addition to those noted above, are at work, such as L1-to-L2 transfer differences or varied L2 socialization experiences in their respective communities. Alternatively, it may be a combination of these or other as yet unidentified variables.

Learners who arrive at a younger age struggle more to develop their academic language than older-arriving learners (Roessingh \& Kover, 2003). These researchers found that older learners were able to transfer language and literacy concepts that they had already developed in their first language. Younger learners were found to be disadvantaged in two ways. First, they had no first-language knowledge of the content area literacy concepts that they were expected to learn, so they had nothing to build on in their content classes. Second, because they were no longer exposed to first-language academic environments, they were unable to develop the L1 conceptual knowledge necessary to facilitate their L2 CALP acquisition.

Findings in our study suggest significant differences in long-term academic achievement related to ethnolinguistic group. These suggest that the "myth of the model minority" that all Asian students excel academically is false because some Asian subgroups do not do well. Findings also suggest that both lower academic achievement and higher mobility rates are associated with socioeconomic status. Pedagogy must take into account the difficulties associated with teaching highly mobile student populations. In 
addition, it is clear that pedagogy must also take into account that some groups such as Cantonese-speaking boys may be in academic difficulty.

\section{The Authors}

Lee Gunderson is a professor and former head of the Department of Language and Literacy Education in the University of British Columbia, where he teaches both undergraduate and graduate courses in second-language reading, language acquisition, literacy acquisition, and teacher education.

Reginald D'Silva is a doctoral candidate in the Language and Literacy Education Department in the University of British Columbia. His research interests involve the role of digital technologies in promoting literacy skills in EAL learners. He is also interested in issues related to literacy education in the south Asian context.

Dennis Odo is a doctoral candidate in the department of Language and Literacy Education in the University of British Columbia, where he teaches classes in TESOL methods and academic writing. His research interests include second-language literacy assessment, language teacher education, and second-language teaching methodology.

\section{References}

Abada, T., \& Tenkorang, E.Y. (2009). Gender differences in educational attainment among the children of Canadian immigrants. International Sociology, 24, 580-608.

Baker, K.A., \& de Kanter, A.A. (1981). Effectiveness of bilingual education: A review of the literature. Washington, DC: Office of Planning, Budget and Evaluation, US Department of Education.

British Columbia Ministry of Education. (2009). The facts of ESL in British Columbia: Record number of students in ESL graduate. Edufacts.

Canadian Council on Learning. (2008). Understanding the academic trajectories of ESL students. Lessons in learning. Available: http:/ / www.cclcca.ca/CCL/Reports/LessonsinLearning/LinL20081002ESLStudents.html

Crago, M.B. (1992). Communicative interaction and second language acquisition: An Inuit example. TESOL Quarterly, 26, 487-505.

Cummins, J. (1979). Cognitive/academic language proficiency, linguistic interdependence, the optimum age question and some other matters. Working Papers on Bilingualism, 19, 197-205.

Cummins, J. (1980). The entry and exit fallacy in bilingual education. NABE Journal, 4(3), 25-59.

Cummins, J. (1981a). Age on arrival and immigrant second language learning in Canada: A reassessment. Applied Linguistics, 2, 132-149.

Cummins, J. (1981b). The role of primary language development in promoting educational success for language minority students. In J. Cummins (Ed.), Schooling and language minority students: A theoretical framework (pp. 3-49). Los Angeles, CA: California State University.

Cummins, J. (1983a). Heritage language education: A literature review. Toronto, ON: Ministry of Education.

Cummins, J. (1983b). Language proficiency and academic achievement. In J.W. Oller (Ed.), Issues in language testing research (pp. 108-129). Rowley, MA: Newbury House.

Cummins, J. (1984). Bilingualism and special education: Issues in assessment and pedagogy. Clevedon, UK: Multilingual Matters.

Cummins, J., \& Swain, M. (1986). Linguistic interdependence: A central principle of bilingual education. In J. Cummins \& M. Swain (Eds.), Bilingualism in education (pp. 80-95). New York: Longman Group UK Limited.

Garnett, B., Adamuti-Trache, M., \& Ungerleider, C. (2008). The academic mobility of students for whom English is not a first language: The roles of ethnicity, language, and class. Alberta Journal of Educational Research, 54, 309-326. 
Goldenberg, C. (2006). Improving achievement for English learners: Conclusions from 2 research reviews. Colorin Colorado. Available: http://www.colorincolorado.org/article/12918

Gunderson, L. (2007). English-only instruction and immigrant students in secondary schools: A critical examination. Mahwah, NJ: Erlbaum.

Lambert, M., Zeman, K., Allen, M., \& Bussière, P. (2004). Who pursues postsecondary education, who leaves and why: Results from the Youth in Transition Survey. Ottawa: Statistics Canada.

Looker, D., \& Thiessen, V. (2004). Aspirations of Canadian youth for higher education (Final Report SP-600-05-04E). Gatineau, QC: Human Resources and Skills Development Canada.

Louie, V. (2001). Parents' aspirations and investment: The role of social class in the educational experiences of 1.5 and second-generation Chinese Americans. Harvard Educational Review, 71, 438-474.

Menken, K. (2008). English learners left behind: Standardized testing as language policy. Clevedon, UK: Multilingual Matters.

Minichiello, D. (2001). Chinese voices in a Canadian secondary school landscape. Canadian Journal of Education, 26, 77-96.

Pfeifer, M.E., \& Lee, S. (2004). Hmong population, demographic, socioeconomic, and educational trends in the 2000 Census. In B. Thao, L. Schein, \& M. Niedzweicki (Eds.), Hmong 2000 census publication: Data and analysis. Washington, DC: Hmong National Development Inc.

Poole, D. (1992). Language socialization in the second language classroom. Language learning, 42, 593-616.

Portes, A., \& Rumbaut, R.G. (2001). Legacies: The story of the immigrant second generation. Berkeley, CA: University of California Press.

Roessingh, H. (2004). Effective high school ESL programs: A synthesis and meta-analysis. Canadian Modern Language Review, 60, 611-636.

Roessingh, H., \& Kover, P. (2003). Variability of ESL learners' acquisition of cognitive academic language proficiency: What can we learn from achievement measures? TESL Canada Journal, 21, 1-21.

Rumbaut, R.G. (1995). The new Californians: Comparative research findings on the educational progress of immigrant children. In R.G. Rumbaut \& W.A. Cornelius (Eds.), California's immigrant children: Theory, research and implications for educational policy (pp. 1769). San Diego, CA: University of California Press.

Schecter, S.R., \& Bayley, R. (1997). Language socialization practices and cultural identity: Case studies of Mexican-descent families in California and Texas. TESOL Quarterly, 31, 513-541.

Schieffelin, B.B., \& Ochs, E. (Eds.). (1986a). Language socialization across cultures. New York: Cambridge University Press.

Schieffelin, B.B., \& Ochs, E. (1986b). Language socialization. Annual Review of Anthropology, 15, 163-191.

Statistics Canada. (2010). Projections of the diversity of the Canadian population. The Daily. Available: http:/ / www.statcan.gc.ca/daily-quotidien/100309/dq100309a-eng.htm

Steinberg, L. (1996). Beyond the classroom: Why school reform has failed and what parents need to do. New York: Simon \& Schuster.

Toohey, K., \& Derwing, T.M. (2008). Hidden losses: How demographics can encourage incorrect assumptions about ESL high school students' success. Alberta Journal of Educational Research, 54, 178-193.

Watt, D., \& Roessingh, H. (2001). The dynamics of ESL drop-out: Plus ça change ... Canadian Modern Language Review, 58, 203-222.

Willett, J. (1995). Becoming first graders in an L2: An ethnographic study of L2 socialization. TESOL Quarterly, 29, 473-503. 